\title{
CONTROL OF Dalbulus maidis IN MAIZE CROP WITH ELECTROSTATIC SPRAYING
}

\section{CONTROLE DE Dalbulus maidis NA CULTURA DO MILHO COM PULVERIZAÇÃO ELETROSTÁTICA}

\section{Rodrigo Santos MARQUES ${ }^{1}$; João Paulo Arantes Rodrigues da CUNHA ${ }^{2}$; Guilherme Sousa ALVES ${ }^{1}$; Thales Cassemiro ALVES ${ }^{1}$; Sérgio Macedo SILVA ${ }^{1}$; César Henrique Souza ZANDONADI ${ }^{1}$}

1. Institute of Agricultural Science, Federal University of Uberlândia, Uberlândia, MG, Brazil; 2. Institute of Agricultural Science, Federal University of Uberlândia, Uberlândia, MG, Brazil, jpcunha@ufu.br.

\begin{abstract}
Among the pests that attack the maize, the maize leafhopper, which causes direct damages by sap-sucking and indirect ones, stands out as being a vector of pathogens and viruses, and can cause losses of up to $100 \%$ of the production. An alternative to improve the chemical control of this pest is the use of electrostatic spraying technology. However, there is no research support. This study aimed to evaluate the deposition of spray in the maize crop and the effectiveness in the chemical control of the maize leafhopper, using the electrostatic spraying system, at different application rates, compared to the conventional spraying system. The experiment was conducted in a randomized block design with five treatments, in a $2 \times 2+2$ factorial scheme: presence or absence of electrostatic spraying system, two application rates ( 35 and $\left.50 \mathrm{~L} \mathrm{ha}^{-1}\right)$, an additional treatment using a hydraulic spray nozzle and a rate of $100 \mathrm{~L} \mathrm{ha}^{-1}$, and other additional treatment without the application of insecticide, in order to support the study of pest infestation. Each treatment consisted of eight replicates, in which the spray deposition in the maize canopy and the efficiency in the control were evaluated. For the insecticide applications, a boom sprayer with induction electrostatic spraying system was used with indirect electrification. To evaluate the deposition, the Brilliant Blue FCF marker was added to the spray to be detected by absorbance in spectrophotometry. For the biological efficacy of the maize leafhopper, the insecticide composed of thiamethoxam and lambda-cyhalothrin was used compared with the control without the application. There was a significant increase in the spray deposition, both in the upper and lower maize leaves, with the use of electrostatic spray technology compared to the conventional spray system. The control of the maize leafhopper was also superior. The electrostatic spraying also made it possible to reduce the application rate by approximately three times in relation to that used in conventional hydraulic spraying.
\end{abstract}

KEYWORDS: Application technology. Electrostatic sprayer. Corn leafhopper.

\section{INTRODUCTION}

The maize (Zea mays L.) is one of the main cereals produced in Brazil. Among the pests that attack the crop, we highlight the maize leafhopper, which has been assuming an important role in recent years. The Dalbulus maidis (DeLong \& Wolcott) (Hemiptera: Cicadellidae) is considered one of the primary vector species of pathogens (NAULT; AMMAR, 1989), besides causing direct damage by sap-sucking (BUSHING; BURTON, 1974). The main damages are due to the transmission of pathogens such as Spiroplasma kunkelii (CSS- corn stunt spiroplasma), maize phytoplasma (MBSPmaize bushy stunt phytoplasma) and maize streak virus (MRFV-maize rayado fino virus) (KITAJIMA et al., 1984; KITAJIMA; NAZARENO, 1985), causing diseases such as maize stunt and virus diseases, such as rayado-fino (KUNKEL, 1946; KITAJIMA,1979). These pathogens can cause losses of up to $100 \%$ of maize production depending on the time of infection and the hybrid used (NAULT, 1990).

The control of this Hemiptera is mainly based on the use of tolerant hybrids, selective insecticides application and seeds treatment. However, even with the existence of insecticidal molecules of good efficacy, the application technology is still a limiting factor, since the quality of the deposition directly influences the biological efficacy of these molecules (OZEKI; KUNZ, 1998).

According to Cunha et al. (2008), in the crop protection treatments, much attention is necessary to the products used, but the technology for its application is often left in the background. The applications need to overcome the barrier imposed by the leaves mass and thus promote good coverage inside the plant (OZKAN et al., 2006; ZHU et al., 2008). The use of suitable techniques, which favor the deposit of product in the target, is 
one of the ways to increase the effectiveness of the treatments, besides reducing the losses like drift and runoff (CUNHA, 2008; RODRIGUES et al., 2010; SOUZA et al., 2011; VAN ZYL et al., 2013).

As an alternative to improve the quality of applications of crop protection products, the use of electrostatic spraying technology has increased. Researches about these systems began in the 1970s with the development of an electrostatic pneumatic nozzle prototype by Law (1978) at the University of Georgia.

Some researches have shown the advantages of the electrostatic spraying (XIONGKUI et al., 2011; MASKI; DURAIRAJ, 2010; DERKSEN et al., 2007b; LARYEA; NO, 2005). Maski and Durairaj (2010) explained that electrostatic forces on small droplets are more prominent than the gravitational forces and therefore, electrostatic charging of spray droplets can provide an improved deposition with reduced drift. Chaim (2006) stated that the electrostatic system works better with fine and extremely fine droplets. In this droplet quality, the electric forces can be introduced into sufficient magnitude to control their movement.

The technology consists in loading the droplet with positive or negative charges, by forming an electric field at the nozzle tip that can minimize the deviation of the droplet from its trajectory to the target and causes attraction between both. For this, it is necessary to cause an imbalance in the electric charges of the droplet, with supply or extraction of electrons. In this way, charges of the same signal repel each other and loads of opposing signals attract each other, and the charge of an electrified body induces an equal charge and an opposite on some other grounded conductive body. Then, the cloud of electrified droplets when approaching the plant, a neutral and grounded object, causes an imbalance between protons and electrons, induces an opposite signal charge on the surface of the target and, thus, promote attraction between charges (CHAIM, 2006).

However, there are still doubts about this technology. There have been studies with electrostatic spraying where no improvement has been observed in the application (SILVA et al., 1997; SILVA et al., 2000; BAYER et al., 2011 and MAGNO JUNIOR et al., 2011). Silva et al. (1997) explained that the induced electric charge was not sufficient to promote greater spray deposition on the target. Bayer et al. (2011) suggested that drift and droplet evaporation can reduce the effectiveness of the electrostatic system. Magno Júnior et al. (2011) showed that the electrostatic system was not capable to promote a good coverage inside the citrus plant canopy.

In this way, this study aimed to evaluate the deposition of spray in the maize crop and the effectiveness in the chemical control of the maize leafhopper, using the electrostatic spraying system, at different application rates, compared to the conventional spraying system.

\section{MATERIAL AND METHODS}

The experiment was carried out at "Fazenda Boa", located in Tapuirama, Uberlândia district (Minas Gerais, Brazil), with an average elevation of $880 \mathrm{~m}$ and vegetation characteristic of Brazilian Savana - "Cerrado". The climate of the region was classified as Cwa, by the Köppen System, presenting a warm and temperate climate with higher rainfall in the summer, with annual average rainfall of $1.443 \mathrm{~mm}$ and annual average temperature of $21.2^{\circ} \mathrm{C}$.

The experiment was conducted in a randomized complete block design. The experimental plots were composed of $20 \mathrm{~m}$ long and $6 \mathrm{~m}$ wide, with a useful plot of $15 \mathrm{~m}$ in length and 4 $\mathrm{m}$ in width, the remainder was considered border. We evaluated six treatments in a $2 \times 2+2$ factorial scheme: presence or absence of electrostatic system, two application rates (35 and $50 \mathrm{~L} \mathrm{ha}^{-1}$ ), one additional treatment using a hydraulic spray nozzle and a $100 \mathrm{~L} \mathrm{ha}^{-1}$ rate, and another additional treatment without the application of insecticide, in order to support the study of pest infestation (Table 1). Each treatment consisted of eight replicates, in which we evaluated the deposition of spray in the maize canopy and the efficiency in the control of the maize leafhopper.

The application with the turned off electrostatic system was adopted to simulate the conventional low rate applications already used in the field, and to compare them with the electrostatic applications.

The maize hybrid used was the 610 Dow (life-cycle duration from 130 to 150 days), sown in March 2017, with $0.50 \mathrm{~m}$ line spacing, totaling a population of 60 thousand plants per ha. The insecticide applications were carried out when the maize was in the V5 phenological stage, with the plants about $0.60 \mathrm{~m}$ of height.

An FM Copling (Araraquara, Brazil) mounted hydraulic sprayer was used, with a $400 \mathrm{~L}$ spray tank, $12 \mathrm{~m}$ boom and 24 nozzles. The height of the spray boom in relation to the crop was $0.4 \mathrm{~m}$ and the distance between nozzles was $0.5 \mathrm{~m}$. The application rates and average displacement speeds 
are shown in Table 1. In this sprayer was installed an Electrostatic Spraying Kit of the SPEElectrostatic Spraying System brand (Porto Alegre, Brazil). The system produces a high voltage electric field $(5000 \mathrm{~V})$ at the base of the spray jet produced by hollow cone nozzles, electrically charging the droplets. The charge is generated due to the electric field produced by induction rings connected to a high voltage generator.

Table 1. Description of the treatments used

\begin{tabular}{llllll}
\hline Treatments & Electrostatic system & Nozzle & Velocity $\left(\mathrm{km} \mathrm{h}^{-1}\right)$ & Pressure $(\mathrm{kPa})$ & Application rate $\left(\mathrm{L} \mathrm{ha}^{-1}\right)$ \\
\hline 1 & On & SPE 1 & 10.3 & 400 & 35 \\
2 & Off & SPE 1 & 10.3 & 400 & 35 \\
3 & On & SPE 1 & 7.2 & 400 & 50 \\
4 & Off & SPE 1 & 7.2 & 400 & 50 \\
5 & Off & MAG 2 & 7.2 & 400 & 100 \\
6 & Control without application & & & \\
\hline
\end{tabular}

During the applications, the environmental conditions: temperature, relative air humidity and wind speed were monitored using the Kestrel ${ }^{\mathbb{B}} 4000$ model thermo-hygro digital anemometer equipment (Boothwyn, USA). The temperature varied from 25 to $30^{\circ} \mathrm{C}$, the relative humidity from $60 \%$ to $68 \%$ and the wind speed from 7 to $9 \mathrm{~km} \mathrm{~h}^{-1}$.

In the treatments with the electrostatic spraying system, a hollow cone ceramic nozzle, supplied by the company SPE with the Electrostatic Kit, denominated by the company as SPE 1, were used. At the pressure used in the test $(400 \mathrm{kPa})$, according to the manufacturer, the nozzles produce droplets with volumetric median diameter (VMD) of $115 \mu \mathrm{m}$ and flow rate of $0.30 \mathrm{~L} \mathrm{~min}^{-1}$.

In the conventional treatment, the hollow cone spray nozzles produced in ceramics by Magnojet (Ibaiti, Brazil), MAG 02 model were used. At the pressure used in the test $(400 \mathrm{kPa})$, the nozzle produces a flow rate of $0.60 \mathrm{~L} \mathrm{~min}{ }^{-1}$. According to Bueno et al. (2013), at $414 \mathrm{kPa}$, this nozzle produces a VMD droplet spectrum of 113 $\mu \mathrm{m}$.

In order to evaluate the deposition of spray in the maize canopy, a marker composed of the food color Brilliant Blue FCF, internationally cataloged by the Food, Drug \& Cosmetic as FD\&C Blue n.1, was added to the spray at the fixed dose of $400 \mathrm{~g}$ of dye per hectare to be detected by absorbance in the spectrophotometry.

A spectrophotometer of the Biospectro ${ }^{\circledR}$ brand (Curitiba, Brazil), SP-22 model, was used, with glass buckets of $3.5 \mathrm{~mL}$ and optical path of 10 $\mathrm{mm}$, with tungsten-halogen lamp to perform the readings. The quantification of the staining was done by absorbance at $630 \eta \mathrm{m}$, the detection range of the blue dye used.
In the spray deposition study, after the spraying, five plants were randomly assigned to each plot and, in each plant, two leaves were collected: one in the upper third $(60 \mathrm{~cm}$ high) and the other in the lower third of the plant $(15 \mathrm{~cm}$ high), close to the main stem. The leaves were then grouped by position in the plant and placed in plastic bags. These bags were packed in containers with thermal and light insulation for transportation to the Agricultural Mechanization Laboratory of the Federal University of Uberlândia (Uberlândia, Minas Gerais, Brazil), where the analyzes were carried out.

In the laboratory, $100 \mathrm{~mL}$ of distilled water was added to each plastic bag. They were closed and shaken for $30 \mathrm{~s}$ to homogenize the dye present in the samples. Afterwards, the liquid was removed and transferred to plastic cups, which were packed in a refrigerated room with light insulation for 24 hours for later reading of absorbance in the spectrophotometer. The leaf area was measured with a Licor LI 3100C leaf area meter (Lincoln, USA). They were measured, being the sum of the 10 leaves of each plot computed for later deposits determination.

Through a calibration curve, originated by dye standard solutions, the equation was obtained: $y$ $=0.0151 \mathrm{x}-0.0008$, where $\mathrm{y}=$ absorbance and $\mathrm{x}=$ concentration $\left(\mathrm{R}^{2}=99.9 \%\right)$. With this, the absorbance data, obtained in spectrophotometry, were transformed into concentration (ng L $\left.{ }^{-1}\right)$. From the initial concentration of the spray and the dilution volume of the samples, the dye mass retained in the maize leaves collected in the plots was determined. The total deposit was divided by the leaf area of each sample, to obtain the amount in ng of dye per $\mathrm{cm}^{2}$ of leaf area. 
For the biological efficacy evaluation of the maize leafhopper, the insecticide was added in the spray, composed of thiamethoxam $\left(141 \mathrm{~g} \mathrm{~L}^{-1}\right)$ and lambda-cyhalothrin $\left(106 \mathrm{~g} \mathrm{~L}^{-1}\right)$ at a dose of $300 \mathrm{~mL}$ $\mathrm{ha}^{-1}$. It is a systemic product of contact and ingestion, of the chemical group of the neonicotinoids and pyrethroid, and concentrated suspension formulation (CS). In the biological efficacy study, two plants were randomly chosen in each plot. Each plant, at the time of evaluation, had its corncob and upper leaves wrapped in a transparent plastic bag in order to capture the insects for quantification of its population. Two evaluations were performed, the first one was done two days after the application and the second eight days after the application. The percent of control was calculated by the Abbott's formula (ABBOTT, 1925).

In relation to the statistical analyzes, the data presuppositions were initially tested. To verify the homogeneity of the variances and the normality of the residues, the Levene and Shapiro Wilk tests, respectively, were applied using the SPSS statistical software, 20.0 version (SPSS In., Chicago, IL, USA). Subsequently, the data were subjected to Snedecor's F-test at 0.05 significance. For the comparison of means of the factorial analysis,
Tukey's test was applied, and whereas the comparison between the data of the additional treatment with the data of the factorial analysis was performed by the Dunnett test. Were used the ASSISTAT, 7.6 beta version, statistical program (SILVA; AZEVEDO, 2009) at 0.05 significance.

\section{RESULTS AND DISCUSSION}

In the evaluation of the tracer deposition in the upper leaves of the maize crop (Table 2), there was no significant interaction between the application rate and the electrostatic spraying system, indicating a relation of non-dependence between the two factors.

When turned on, electrostatic system provided higher deposition of the spray than when it was turned off, regardless of the application rate, the deposition difference, considered significant, was $533 \mathrm{ng} \mathrm{cm}^{-2}$, an increase of approximately $64 \%$ with the use of electrostatic technology. The electrostatic system also proved superior to the conventional application of $100 \mathrm{~L} \mathrm{ha}^{-1}$, generating a deposition increment of approximately $56 \%$. With the system turned off, there was no difference compared to conventional treatment.

Table 2. Deposition of the tracer spray on maize upper leaves due to electrostatic system and application rate

\begin{tabular}{|c|c|c|c|}
\hline \multirow{3}{*}{ Electrostatic } & \multicolumn{3}{|c|}{ Spray Deposition $\left(\mathrm{ng} \mathrm{cm}^{-2}\right)$} \\
\hline & \multicolumn{2}{|c|}{ Application Rate $\left(\mathrm{L} \mathrm{ha}^{-1}\right)$} & \multirow{2}{*}{ Average } \\
\hline & 35 & 50 & \\
\hline & \multicolumn{2}{|c|}{ Control $\left(100 \mathrm{~L} \mathrm{ha}^{-1}\right): 873.00$} & \multirow{5}{*}{$\begin{array}{l}1360.00 \mathrm{~A} \\
827.00 \mathrm{~B}\end{array}$} \\
\hline On & $1421.00^{+}$ & $1298.00^{+}$ & \\
\hline Off & 875.00 & 780.00 & \\
\hline Average & $1148.00 \mathrm{a}$ & $1039.00 \mathrm{a}$ & \\
\hline CV & $23.50 \%$ & & \\
\hline
\end{tabular}

$\mathrm{Ft}=1.56^{\mathrm{ns}} ; \mathrm{Fe}=37.32^{* *} ; \mathrm{Ft} \mathrm{x} \mathrm{e}=0.02^{\mathrm{ns}} ; \mathrm{Fi} \mathrm{x} \mathrm{c}=5.11^{* *}$

Averages followed by distinct letters, lowercase in the row and upper case in the column, differ from each other by the Tukey test at the 0.05 level of significance. Averages followed by + differ from control treatment by the Dunnett test at 0.05 significance. Ft, Fe, Ft x e and $\mathrm{Fi}$ x c: $\mathrm{F}$ values calculated for application rate, electrostatic system, rate and electrostatic interaction and interaction between factorial and control treatment. ns Not significant at $\alpha=0.05$; $*$ Significant at $\alpha=0.05$; ** Significant at $\alpha=0.01$. CV: coefficient of variation.

In the evaluation of the tracer deposition in the lower leaves of the maize crop (Table 3), there was significant interaction between the application rate and the electrostatic spraying system, indicating a relation of dependence between the two factors.

The rate of $35 \mathrm{~L} \mathrm{ha}^{-1}$ generated higher deposition than the rate of $50 \mathrm{~L} \mathrm{ha}^{-1}$, both with the electrostatic system turned on and off. However, the turned on electrostatic system also provided higher deposition of spray at both application rates, when compared to the same turned off. At the rate of $35 \mathrm{~L}$ $\mathrm{ha}^{-1}$, the deposition difference was $823 \mathrm{ng} \mathrm{cm}^{-2}$, an increase of approximately $97 \%$, and at a rate of $50 \mathrm{~L}$ $\mathrm{ha}^{-1}$, the deposition difference was $488 \mathrm{ng} \mathrm{cm}^{-2}$, an increase of approximately $79 \%$ with the use of electrostatic technology. The turned on electrostatic system, regardless of the rate, also proved superior to the conventional application of $100 \mathrm{~L} \mathrm{ha}^{-1}$, generating an increase of approximately $182 \%$. With the system turned off, there was only a difference in relation to the additional treatment of $100 \mathrm{~L} \mathrm{ha}^{-1}$ in the rate of $35 \mathrm{~L} \mathrm{ha}^{-1}$, with a $72 \%$ increase. 
Table 3. Deposition of the tracer spray on maize lower leaves due to electrostatic system and application rate

\begin{tabular}{llll}
\hline & \multicolumn{2}{l}{ Spray Deposition $\left(\mathrm{ng} \mathrm{cm}^{-2}\right)$} & \\
Electrostatic & Application Rate $\left(\mathrm{L} \mathrm{ha}^{-1}\right)$ & Average \\
\hline & 35 & 50 & 1388.00 \\
On & Control $\left(100 \mathrm{~L} \mathrm{ha}^{-1}\right): 492,00$ & 732.00 \\
Off & $1669.00 \mathrm{aA}^{+}$ & $1106.00 \mathrm{bA}^{+}$ & \\
Average & $846.00 \mathrm{aB}^{+}$ & $618.00 \mathrm{bB}$ & \\
$\mathrm{CV}$ & 1258.00 & 862.00 & \\
\hline $\mathrm{Ft}=25.17^{* *} ; \mathrm{Fe}=69.08^{* *} ; \mathrm{Ft} \mathrm{x} \mathrm{e}=4.48^{*} ; \mathrm{Fi} \mathrm{x} \mathrm{c}=41.41^{* *}$ & & \\
\hline
\end{tabular}

Averages followed by distinct letters, lowercase in the row and upper case in the column, differ from each other by the Tukey test at the 0.05 level of significance. Averages followed by + differ from control treatment by the Dunnett test at 0.05 significance. Ft, Fe, Ft x e and Fi x c: F values calculated for application rate, electrostatic system, rate and electrostatic interaction and interaction between factorial and control treatment. ns Not significant at $\alpha=0.05$; $*$ Significant at $\alpha=0.05$; ** Significant at $\alpha=0.01$. CV: coefficient of variation.

The increase of the spray deposition with the use of the system of electrostatic spraying was also found in other researches. Sazaki et al. (2015) found that the electrostatic spraying provided an increase in the deposition of the spray by $37 \%$. Zheng et al. (2002) also stated that the electrostatic spraying can improve the distribution and deposition of droplets in the plant, with lower environmental contamination, reduced application rates, lower operational cost and better efficiency in crop protection control compared to conventional ones. Zhou et al. (2012) reported that the electrostatic system can increase the deposition by up to $60 \%$, reduce losses by up to $50 \%$ and reduce costs by up to $20 \%$ when compared to other spray techniques. This increase in the spray deposition can be justified by the fact that the electrostatic technology generates attraction between the spray droplets and the plant, generating greater coverage of the target and greater uniformity of the application on the plant. In addition, the electrified droplets are attracted to the abaxial part of the leaves, causing the droplets that would be lost to the soil change their trajectory and settle in these places, favoring the cover where in conventional systems would be practically nonexistent, as in lower part of the plants, thus increasing the amount of droplets retained in the plant and reducing the losses of droplets to the soil.

According to Chaim et al. (2006), several researches have shown that the use of fine droplets provides the best results in the control of crop protection problems. However, as the droplets with small masses have little kinetic energy, they suffer great drift effect with low capture by the targets, thus this greater efficiency using fine droplets, only occurs under very special conditions.

Another important characteristic to be analyzed comes from the comparison of the spray deposition generated between different application rates. Even with rates almost 3 times higher when compared to the rates of $35 \mathrm{~L} \mathrm{ha}^{-1}$ with the presence of the electrostatic system, the conventional application with $100 \mathrm{~L} \mathrm{ha}^{-1}$ did not promote the spray deposition gain. Derksen et al. (2007a) also found similar results evaluating the electrostatic application in sweet peppers. The authors used rates six times lower than those used in conventional treatments.

In Table 4, the first evaluation of biological efficacy was carried out 2 days after the application of the insecticide. There was no significant interaction between the application rate and the electrostatic spraying system, indicating a relation of non-dependence.

The turned on electrostatic system, at both evaluated rates, provided greater control of the leafhopper than when it was turned off. The control difference, considered significant, was $29 \%$. The turned on electrostatic system also proved superior to the conventional application of $100 \mathrm{~L} \mathrm{ha}^{-1}$, generating an increase of approximately $46 \%$. With the system turned off, there was no difference compared to the conventional treatment.

In the second evaluation of the biological efficacy (Table 5) carried out 8 days after the application, there was a significant interaction between the application rate and the electrostatic spraying system. With the turned on electrostatic spraying system, the rate of $35 \mathrm{~L} \mathrm{ha}^{-1}$ generated greater control of the leafhopper than the rate of 50 $\mathrm{L} \mathrm{ha}^{-1}$, but in the absence of the system, the rate of $50 \mathrm{~L} \mathrm{ha}^{-1}$ was higher than the lowest rate.

The turned on electrostatic system provided greater control when compared to the control obtained when it was off. In the rate of $35 \mathrm{~L} \mathrm{ha}^{-1}$, the difference of control was $65 \%$, and with the rate of $50 \mathrm{~L} \mathrm{ha}^{-1}$, the difference of the control was $23 \%$. Both the turned on and off electrostatic system, 
regardless of the rate, were shown to be superior to the conventional application with $100 \mathrm{~L} \mathrm{ha}^{-1}$.

Table 4. Percentage of control of the maize leafhopper ( $1^{\text {st }}$ evaluation - 2 D.A.A.) after application of insecticide with electrostatic system at different rates of application

\begin{tabular}{|c|c|c|c|}
\hline \multirow{3}{*}{ Electrostatic } & \multicolumn{3}{|c|}{ Percentage of Control (\%) } \\
\hline & \multicolumn{3}{|c|}{ Application Rate $\left(\mathrm{L} \mathrm{ha}^{-1}\right)$} \\
\hline & 35 & 50 & Average \\
\hline \multicolumn{4}{|c|}{ Control $\left(100 \mathrm{~L} \mathrm{ha}^{-1}\right): 8.00$} \\
\hline On & $55.00^{+}$ & $53.00^{+}$ & $54.00 \mathrm{~A}$ \\
\hline Off & 26.00 & 24.00 & $25.00 \mathrm{~B}$ \\
\hline Average & $41.00 \mathrm{a}$ & $39.00 \mathrm{a}$ & \\
\hline $\mathrm{CV}$ & $58.00 \%$ & & \\
\hline \multicolumn{4}{|c|}{$\mathrm{Ft}=0.09^{\mathrm{ns}} ; \mathrm{Fe}=17.86^{* *} ; \mathrm{Ft} \times \mathrm{e}=0.01 \mathrm{~ns} ; \mathrm{Fi} \times \mathrm{c}=16.66^{* *}$} \\
\hline \multicolumn{4}{|c|}{$\begin{array}{l}\text { Averages followed by distinct letters, lowercase in the row and upper case in the column, differ from each other by the Tukey test at } \\
\text { the } 0.05 \text { level of significance. Averages followed by }+ \text { differ from control treatment by the Dunnett test at } 0.05 \text { significance. Ft, Fe, Ft } \\
\text { x e and Fi x c: F values calculated for application rate, electrostatic system, rate and electrostatic interaction and interaction between } \\
\text { factorial and control treatment. ns Not significant at } \alpha=0.05 \text {; } \text { Significant at } \alpha=0.05 \text {; * Significant at } \alpha=0.01 \text {. CV: coefficient of } \\
\text { variation. }\end{array}$} \\
\hline
\end{tabular}

Table 5. Percentage of control of the maize leafhopper $\left(2^{\text {nd }}\right.$ evaluation -2 D.A.A. $)$ after the application of insecticide with electrostatic system at different application rates

\begin{tabular}{|c|c|c|c|}
\hline \multirow{3}{*}{ Electrostatic } & \multicolumn{3}{|c|}{ Percentage of Control (\%) } \\
\hline & \multicolumn{2}{|c|}{ Application Rate $\left(\mathrm{L} \mathrm{ha}^{-1}\right)$} & \multirow{2}{*}{ Average } \\
\hline & 35 & 50 & \\
\hline \multicolumn{4}{|c|}{ Control $\left(100 \mathrm{~L} \mathrm{ha}^{-1}\right): 31$} \\
\hline On & $78.00 \mathrm{aA}^{+}$ & $66.00 \mathrm{bA}^{+}$ & 72.00 \\
\hline Off & $13.00 \mathrm{bB}^{+}$ & $43.00 \mathrm{aB}^{+}$ & 28.00 \\
\hline Average & 45.00 & 55.00 & \\
\hline $\mathrm{CV}$ & $18.30 \%$ & & \\
\hline \multicolumn{4}{|c|}{$\mathrm{Ft}=10.03^{* *} ; \mathrm{Fe}=213.05^{* *} ; \mathrm{Ft} \times \mathrm{e}=51.02^{* *} ; \mathrm{Fi} \mathrm{x} \mathrm{c}=31.59^{* *}$} \\
\hline \multicolumn{4}{|c|}{$\begin{array}{l}\text { Averages followed by distinct letters, lowercase in the row and upper case in the column, differ from each other by the Tukey test at the } \\
0.05 \text { level of significance. Averages followed by }+ \text { differ from control treatment by the Dunnett test at } 0.05 \text { significance. Ft, Fe, Ft } \mathrm{e} \text { e } \\
\text { and Fi x c: F values calculated for application rate, electrostatic system, rate and electrostatic interaction and interaction between } \\
\text { factorial and control treatment. ns Not significant at } \alpha=0.05 ;{ }^{*} \text { Significant at } \alpha=0.05 \text {; * Significant at } \alpha=0.01 \text {. CV: coefficient of } \\
\text { variation. }\end{array}$} \\
\hline
\end{tabular}

The greater control of the leafhopper with the use of the electrostatic spray was possibly due to the higher spray deposition generated in the applications. In addition, a possibly higher coverage in places of difficult penetration in the plant, due to the smaller droplets, such as the whorl, the predominant place of occurrence of the leafhopper, should have contributed with the results achieved.

Chaim et al. (2002) found that the electrostatic sprayer provided deposits of about $70 \%$ of the applied product, whereas conventional spraying provided only $30 \%$, in studies comparing the conventional spraying and the electrostatic system. Thus, the electrostatic spraying can increase the effectiveness of crop protection treatments, mainly by favoring the deposition of the active ingredients on the targets, in addition to reducing the application rate and spray losses (MAYNAGH et al., 2009; SASAKI et al., 2015).

\section{CONCLUSIONS}

The electrostatic spraying ( 35 and $50 \mathrm{~L} \mathrm{ha}^{-1}$ ) resulted in higher maize spray deposition and greater chemical control of the maize leafhopper, compared to the turned off system and the conventional system application (hydraulic nozzle and $100 \mathrm{~L} \mathrm{ha}^{-1}$ ).

The electrostatic spraying made it possible to reduce the application rates compared to those used in conventional (non-electrostatic) systems, with a gain in the deposition of the spray, without compromising the biological effectiveness of the products. 
RESUMO: Dentre as pragas que atacam a cultura do milho, atualmente destaca-se a cigarrinha do milho, causadora de danos diretos pela sucção de seiva e indiretos por ser um vetor de patógenos e vírus, podendo causar perdas de até $100 \%$ da produção. Uma alternativa para melhorar o controle químico desta praga é o uso da tecnologia de pulverização eletrostática, no entanto, ainda sem o devido respaldo da pesquisa. Esse trabalho objetivou avaliar a deposição de calda e a eficácia no controle da cigarrinha do milho, utilizando o sistema de pulverização eletrostática, comparado ao sistema convencional, em diferentes taxas de aplicação. O experimento foi conduzido no delineamento de blocos casualizados com cinco tratamentos, em esquema fatorial 2x2+2: presença ou ausência de sistema de pulverização eletrostático, duas taxas de aplicação (35 e 50 $\mathrm{L} \mathrm{ha}^{-1}$ ), um tratamento adicional, empregando ponta de pulverização hidráulica e taxa de $100 \mathrm{~L} \mathrm{ha}^{-1}$, e outro tratamento adicional sem aplicação de inseticida, com intuito de embasar o estudo de infestação da praga. Cada tratamento constou de oito repetições, nas quais foram avaliadas as deposições de calda e a eficácia no controle. Para as aplicações do inseticida, foi utilizado um pulverizador de barra com sistema de pulverização eletrostática por indução com eletrificação indireta. Para a avaliação da deposição, adicionou-se à calda o marcador Azul Brilhante para ser detectado por absorbância em espectrofotometria. Para a avaliação de eficácia biológica da cigarrinha do milho, foi utilizado o inseticida composto por tiametoxam e lambda-cialotrina, comparando com a testemunha sem aplicação. Houve um incremento significativo na deposição de calda, tanto nas folhas superiores quanto nas folhas inferiores do milho, com o uso da tecnologia de pulverização eletrostática comparada ao sistema de pulverização convencional. O controle fitossanitário da cigarrinha do milho também se mostrou superior. A pulverização eletrostática possibilitou ainda a redução da taxa de aplicação em aproximadamente três vezes em relação à utilizada na pulverização hidráulica convencional.

PALAVRAS-CHAVE: Tecnologia de aplicação. Pulverizador eletrostático. Cigarrinha do milho.

\section{REFERENCES}

ABBOTT, W. S. A method of computing the effectiveness of an insecticide. Journal of Economic Entomology, Lanham, v. 18, n. 1, p. 265-267, 1925. https://doi.org/10.1093/jee/18.2.265a

BAYER, T.; COSTA, I. F. D.; LENZ, G.; ZEMOLIN, C.; MARQUES, L. N.; STEFANELO, M. S. Equipamentos de pulverização aérea e taxas de aplicação de fungicida na cultura do arroz irrigado. Revista Brasileira Engenharia Agrícola Ambiental, Campina Grande, v. 15, n. 2, p. 192-198, 2011. https://doi.org/10.1590/S1415-43662011000200007

BUENO, M. R.; CUNHA, J. P. A. R.; ROMAN, R. A. A. Tamanho de gotas de pontas de pulverização em diferentes condições operacionais por meio da técnica de difração do raio laser. Engenharia Agrícola, Jaboticabal, v. 34, n. 5, p. 976-985, 2013. https://doi.org/10.1590/S0100-69162013000500009

BUSHING, R. W.; V. E. BURTON. Leafhopper damage to silage corn in California. Journal Economic Entomology, Califórnia, v. 67, n. 5, p. 656-658, 1974. https://doi.org/10.1093/jee/67.5.656

CHAIM, A.; PESSOA, M. C. P. Y.; FERRACINI, V. L. Eficiência de deposição de agrotóxicos, obtida com bocal eletrostático para pulverizador motorizado costal. Pesquisa Agropecuária Brasileira, Brasília, v. 37, n. 4, p. 497-501, 2002. https://doi.org/10.1590/S0100-204X2002000400011

CHAIM, A. Pulverização eletrostática: principais processos utilizados para eletrificação de gotas. Jaguariúna: Embrapa Meio Ambiente, 2006. 17p. (Embrapa Meio Ambiente. Documentos, n.57). https://doi.org/10.5380/pes.v17i0.3181

CUNHA, J. P. A. R.; MOURA, E. A. C.; SILVA JUNIOR, J. L.; ZAGO, F. A.; JULIATTI, F. C. Efeito de pontas de pulverização no controle químico da ferrugem da soja. Engenharia Agrícola, Jaboticabal, v. 28, n. 2, p. 283-291, 2008. https://doi.org/10.1590/S0100-69162008000200009 
DERKSEN, R. C.; ZHU, H.; FOX, R. D.; BRAZEE, R. D.; KRAUSE, C. R. Coverage and drift produced by air induction and conventional hydraulic nozzles used for orchards applications. Transaction of the ASABE, St. Joseph, v. 50, n. 5, p. 1493-1501, 2007b. https://doi.org/10.13031/2013.23941

DERKSEN, R. C.; VITANXA, S.; WELTY, C.; MILLER, S.; BENNETT, M.; ZHU, H. Field evaluation of application variables and plant density for bell pepper pest management. Transactions of the ASABE, St. Joseph, v. 50, n. 6, p. 1945-1953, 2007a. https://doi.org/10.13031/2013.24090

KITAJIMA, E. W. Citopatologia e localização de vírus de milho e de leguminosas alimentícias nas plantas infectadas e nos vetores. Fitopatologia Brasileira, Brasília, v. 4, n. 2, p. 241- 254, 1979.

KITAJIMA, E. W.; RIBEIRO, R. L. D.; LIN, M. T.; RIBEIRO, M. I. S. D.; KIMURA, O.; COSTA, C. L.; PIMENTEL, J. P. Lista comentada de virus e organismos do tipo micoplasma em plantas cultivadas e silvestres do Estado do Rio de Janeiro. Fitopatologia Brasileira, Brasília, v. 9, n. 3, p. 607-625, 1984.

KITAJIMA, E. W.; NAZARENO, N. R. X. Levantamento de vírus e mollicutes de milho, no Estado do Paraná. Fitopatologia Brasileira, Brasília, v. 10, p. 613-625, 1985.

KUNKEL, L. O. Leafhopper transmission of corn stunt. Proceedings of the National Academy of Sciences of the United States of America, Washington, v.32, n.9, p.246-247, 1946. https://doi.org/10.1073/pnas.32.9.246

LARYEA, G. N.; NO, S. Y. Effect of fan speed and electrostatic charge on deposition of orchard canopy sprays. Atomization and Sprays, Redding, v. 15, p. 133-144, 2005. https://doi.org/10.1615/AtomizSpr.v15.i2.20

LAW, S. E. Embedded-electrode electrostatic-induction spray nozzle: theoretical and engineering design.

Transactions of the ASAE, Saint Joseph, v. 21, p. 1096-1104, 1978. https://doi.org/10.13031/2013.35448

MAGNO JÚNIOR, R. G.; TEIXEIRA, M. M.; VIEIRA, L. B.; FERREIRA, L. R.; ALVARENGA, C. B. Desenvolvimento de um dispositivo eletrônico para atração de gotas da aplicação eletrostática em plantas cítricas. Bioscience Journal, Uberlândia, v. 27, n. 5, p. 798-804, 2011.

MASKI, D.; DURAIRAJ, D. Effects of charging voltage, application speed, target height and orientation upon charged spray deposition on leaf abaxial and adaxial surfaces. Crop Protection, Londres, v. 29, n. 2, p. 134141, 2010. https://doi.org/10.1016/j.cropro.2009.10.006

MAYNAGH, B. M.; GHOBADIAN B; JAHANNAMA M. R.; HASHJIN, T. T. Effect of Electrostatic Induction Parameters on Droplets. Charging for Agricultural Application. Journal of Agricultural Science and Technology, Tehran, v. 11, n. 3, p. 249-257, 2009.

NAULT, L. R.; AMMAR, E. D. Leafhopper and planthopper transmission of plant viruses. Annual Review of Entomology, Palo Alto, v. 34. p. 503-529, 1989. https://doi.org/10.1146/annurev.ento.34.1.503

NAULT, L. R. Evolution of insect pest: maize and leafhopper, a case study. Maydica, Guatemala, v. 35, n. 2, p. $165-175.1990$.

OZEKI, Y.; KUNZ, R. P. Tecnologia de aplicação aérea - Aspectos práticos. In: Guedes, J. V. C.; Dornelles S. H. B. (ed.) Tecnologia e segurança na aplicação de agrotóxicos. Santa Maria: UFSM, 1998. p. 65-78.

OZKAN, H. E.; ZHU, H.; DERKSEN, R. C.; GULER, H.; KRAUSE, C. Evaluation of various spraying equipment for effective application of fungicides to control Asian soybean rust. Aspects of Applied Biology, Wellesbourne, v. 77, p. 423-431, 2006.

RODRIGUES, A. C. P.; FILHO, S. I. B. S.; MARTINS, D.; COSTA, N. V.; ROCHA, D. C.; SOUZA, G. S. F. Avaliação qualitativa e quantitativa na deposição de calda de pulverização em Commelina benghalensis. Planta Daninha, Viçosa, v. 28, n. 2, p. 421-428, 2010. https://doi.org/10.1590/S0100-83582010000200022 
SASAKI, R. S.; TEIXEIRA, M. M.; SANTIAGO, H.; MADUREIRA, R. P.; MACIEL, C. F. S.; FERNANDES, H. C. Adjuvantes nas propriedades físicas da calda, espectro e eficiência de eletrificação das gotas utilizando a pulverização eletrostática. Ciência Rural, Santa Maria, v. 45, n. 2, p. 274-279, 2015. https://doi.org/10.1590/0103-8478cr20131604

SILVA, O. R. R. F.; MARQUES, L.; CARVALHO, O. S.; VIEIRA, R. M. Avaliação do depósito de gotas através da pulverização eletrostática e da convencional sobre a cultura do algodoeiro. Revista Brasileira de Engenharia Agrícola Ambiental, Campina Grande, v. 1, n. 2, p. 101-105, 1997. https://doi.org/10.1590/18071929/agriambi.v1n1p101-105

SILVA, O. R. R. F.; CARVALHO, O. S.; MARQUES, L. Determinação das perdas por escorrimento da pulverização eletrostática e convencional sobre o cultivo do algodoeiro herbáceo. Revista Brasileira de Oleaginosas e Fibrosas, Campina Grande, v. 4, n .2, p. 123-130, 2000.

SILVA, F. A. S.; AZEVEDO, C. A. V. Principal components analysis in the software Assistat statistical attendance. In: WORLD CONGRESS ON COMPUTER IN AGRICULTURE, 7, 2009, Reno. Anais... Reno: American Society of Agricultural and Biological Engineers, 2009.

SOUZA, L. A.; CUNHA, J. P. A. R.; PAVANIN, L. A. Eficácia e perda do herbicida 2,4-D amina aplicado com diferentes volumes de calda e pontas de pulverização. Planta Daninha, Viçosa, v. 29, n. 2, p. 1149-1156, 2011. https://doi.org/10.1590/S0100-83582011000500023

VAN ZYL, J. G. J.; FOURIEA, P. H.; SCHUTTEB, G. C. Spray deposition assessment and benchmarks for control of Alternaria brown spot on mandarin leaves with copper oxychloride. Crop Protection, Londres, v. 46, n. 4. p. 80-87, 2013. https://doi.org/10.1016/j.cropro.2012.12.005

XIONGKUI, H.; AIJUN, Z.; YAJIA, L.; JIANLI, S. Precision orchard sprayer based on automatically infrared target detecting and electrostatic spraying techniques. International Journal of Agricultural and Biological Engineering, Pequim, v. 4, n. 1, p. 35-40, 2011.

ZHENG, J.; ZHOU, H.; XU, Y. Advances in pesticide electrostatic spraying research in China. In: ASAE Annual International Meeting/CIGR World Congress, 15, 2002, Chicago, Anais... St. Joseph.: ASAE, 2002. (Paper $n^{\circ}$ 021034).

ZHOU, Y.; QI L.; JIA, S.; ZHENG, X.; MENG, X.; TANG, Z.; SHEN, C. Development and application prospects of pneumatic electrostatic sprayer in orchard. Asian Agricultural Research, Pequim, v.4, n.1, p.78$80,2012$.

ZHU, H.; DERKSEN, R. C.; OZKAN, H. E.; GULER, H.; BRAZEE, R. D.; REDING, M. E.; KRAUSE, C. R. Development of a canopy opener to improve spray deposition and coverage inside soybean canopies. v. 2. Opener design with field experiments. Transactions of the ASABE, St. Joseph, v. 51, n. 6, p. 1913-1922, 2008. https://doi.org/10.13031/2013.25390 